\title{
MACROPRUDENTIAL SUPERVISION: FROM THEORY TO POLICY
}

\section{Dirk Schoenmaker* and Peter Wierts**}

Financial supervision focuses on the aggregate (macroprudential) in addition to the individual (microprudential). But an agreed framework for measuring and addressing financial imbalances is lacking. We propose a holistic approach for the financial system as a whole, beyond banking. Building on our model of financial amplification, the financial cycle is the key variable for measuring financial imbalances. The cycle can be curbed by leverage restrictions that might vary across countries. We make concrete policy proposals for the design of macroprudential instruments to simplify the current framework and make it more consistent.

Keywords: financial cycle; macroprudential policy; financial supervision; leverage ratio

JEL Classifications: E58; G18; G28

\section{Introduction}

Prior to the global financial crisis of 2007-9, mainstream thinking on financial policy was that it was sufficient for central banks and financial supervisors to monitor the soundness of individual financial institutions. But in line with the fallacy of composition, the system as a whole behaves differently from its individual components. A case in point is the fire sale of assets during a downturn. While understandable from the risk management perspective of an individual financial institution that wants to reduce its risk, such selling makes the price decline worse, causing a vicious downward spiral (Shleifer and Vishny, 2011). Another example is that at the top of the credit cycle, individual financial institutions look sound because measured risk is low, while the financial system becomes increasingly fragile as imbalances build up (Minsky, 1986).

That is exactly what happened in the run-up to the global financial crisis. The build-up of financial imbalances made the overall financial system fragile. A subsequent shock (in the form of the Lehmann collapse) led to the unravelling of the imbalances, exacerbated by endogenous feedback loops. The point is that (almost) nobody was watching, let alone preventing, the building up of the imbalances. Yet, Schularick and Taylor (2012) document more than a century of credit booms that turned to bust, with leverage cycles at the core of financial crises (see also the classic on financial panics by Kindleberger and Aliber,
2011). Moreover, the internal models used by banks for risk management assumed, and still assume, that risk is exogenous, while financial risk has a strong endogenous component (Danielsson, 2013).

Hanson, Kashyap and Stein (2011) and Galati and Moessner (2013, 2014) provide excellent surveys on macroprudential supervision. While there is now consensus that financial supervision has to focus on the aggregate (macroprudential), in addition to the individual (microprudential), there is no agreed macroprudential framework for measuring financial imbalances and applying policies to correct such imbalances. This paper focuses on these two open questions in the so-called time dimension of macroprudential policy. The companion paper by Barth and Wihlborg (2016) in this issue, on too-big-to-fail, addresses the cross-sectional dimension of macroprudential policy. In our paper, we argue for a sector-wide approach, beyond banking. The conduct of macroprudential policy is challenging in the Euro Area, where the single monetary policy might aggravate credit growth in certain places, but not in others.

Our preliminary conclusion is that the evolution of macroprudential policy might well follow that of monetary policy. First, the theoretical framework of inflation targeting has been developed. Next, the inflation outlook over the medium term has been measured and 
presented to central bank policymakers. This outlook has been used for analysing the monetary policy stance. Finally, the central bank has decided on its policy rate to 'correct' deviations from the medium-term goal. Although macroprudential policy is more complicated and multi-dimensional (Goodhart, 2014), the cyclical component of macroprudential supervision could follow the monetary path.

This paper follows the same steps. Section 2 discusses the theoretical framework for macroprudential supervision. Section 3 examines emerging approaches to measurement of the financial cycle. Section 4 proposes the use of a common leverage ratio, as a new policy instrument to contain excessive credit growth across the financial system, and suggests concrete steps towards its implementation, building on current legislation and policy discussions. Section 5 concludes.

\section{The theoretical framework'}

Macroprudential supervision is the missing link in the broader monetary and financial policy framework, as the global financial crisis and subsequent euro sovereign crisis painfully highlighted. In several nations, including the United States, Ireland and Spain, spectacular rises in house prices were accompanied by unsustainable credit growth. The bursting of the US bubble was not a microprudential,'bad loan' event, but triggered the largest crisis the world has seen since the Great Depression. The bursting of the Irish and Spanish bubbles threatened national solvency, not just bank solvency.

Central bankers and other macroeconomic policymakers stood by and watched the problems accumulating because

Figure I. Policy framework for the financial and economic system

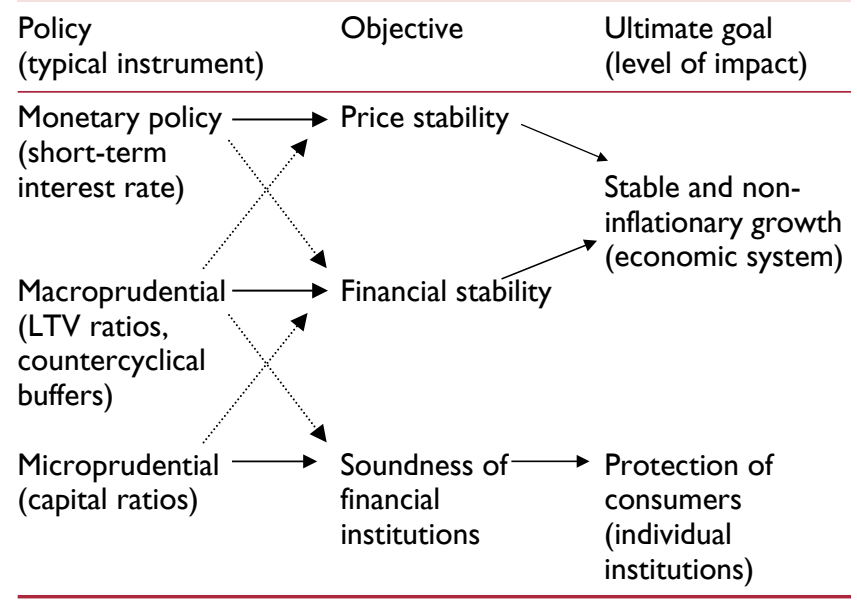

Source: Based on Schoenmaker and Wierts (20II). they thought it was sufficient to conduct monetary policy and microprudential supervision. But the former is only concerned with the inflation of consumer goods, ignoring inflated asset prices in the objective function. And the latter is only concerned with the soundness of individual financial institutions, using internal models that are run on the assumption that risk is exogenous. The global financial and euro sovereign crises showed that the financial system as a whole matters and that the unravelling of risk has endogenous feedback loops (Brunnermeier et al, 2009).

Figure 1 shows the new policy framework and places macroprudential supervision in the middle of monetary policy and microprudential supervision. Macroprudentialism has moved to the centre of the policy agenda (Baker, 2013) and interacts with both other policy areas. Macroprudential supervision operates at the level of the financial system and is concerned with the impact on the wider economy. Asia learned its lesson after its own crisis in the late 1990s, and introduced macroprudential policies earlier. Hong Kong, for example, has adopted an aggressive loan-tovalue policy, under which the Hong Kong Monetary Authority reduces the ratio for new mortgages when house prices are rising too fast.

Central banks are returning to their roots by re-assuming a broad mandate. History teaches us that central banks have always had a dual role: maintaining price stability and financial stability (Goodhart, 2011). Accordingly, financial stability departments of central banks have been strengthened. Moreover, new structures are being put in place to facilitate proper coordination between the major players: finance ministries, central banks and financial supervisors (for details, see ASC, 2014). At the global level, the Financial Stability Board coordinates between the authorities of the major countries.

There is consensus on the broad objectives of macroprudential supervision. With respect to the time dimension, macroprudentialism should increase the resilience of the financial system against financial shocks. But then the disagreement sets in. Borio (2014b), for example, calls for modesty and aims just to increase the resilience of the financial system against financial shocks. In contrast, Gersbach and Rochet (2014) would go further, preferring countercyclical policies to constrain financial booms, which are fuelled by credit growth.

On the overall policy framework, there is a longstanding debate on how monetary and macroprudential policies should interact. Tucker (2014) stresses the role of macroprudential policy as separate from that of 
monetary policy. Macroprudential policy takes a more granular approach by targeting particular markets or sectors, such as housing and property markets. In contrast, Borio (2014b) argues that monetary and macroprudential policies work in tandem since monetary policy influences risk perceptions and risk appetite (the risk-taking channel). A third view is that of Stein (2013), who says that monetary policy is more pervasive because it "gets in all the cracks" of the financial system.

Finally, there is the issue of how to strike the right balance between macroprudentialism and microprudentialism? A number of authors argue that macro stability should have priority over micro soundness (Schoenmaker and Kremers, 2014; Tucker, 2014). Until recently, the prevalent approach to financial stability implicitly assumed that the system as a whole can be made safe by making individual financial institutions safe. But now it is widely agreed that this idea, which was at the basis of original Basel banking supervision, represents a fallacy of composition. The fallacy of composition (Brunnermeier et al, 2009) derives from the fact that, when trying to make themselves safer, financial institutions can behave in a way that collectively undermines the stability of the system. Selling an asset when the price of risk increases may be a prudent response from the perspective of an individual financial institution, but if many financial institutions act in this way, the asset price will collapse, forcing financial institutions to take yet further steps to rectify the situation. The responses of the financial institutions themselves to such pressures lead to generalised declines in asset prices, and enhanced correlations and volatility in asset markets (Shleifer and Vishny, 2011). Insofar as they neglect these general equilibrium effects, microprudential policies can be destructive at the macroeconomic level. In a more reflective mode, Borio (2014b) argues that macroprudentialism stands for an intellectual orientation or lens through which the task of achieving financial stability is understood. Prudential tools should be designed through a macro lens instead of the prevailing micro lens.

\section{I The case for countercyclical macroprudential supervision}

Reinhart and Rogoff (2009) document a long history of debt financed booms and busts, with severe implications for financial stability and the real economy. There are various amplification mechanisms at work in the financial system, which are endogenous. The basic mechanism is that debt financing (leverage) is increased to maximise profits during good times, when asset values (collateral) are high and measured risk is low (Kiyotaki and Moore, 1997; Geanakoplos, 2010). A first example is investment banks, which expand their business with high levels of debt during good times (Adrian and Shin, 2010). Another example is housing finance, with increasingly large mortgages granted during housing booms (Almeida et al, 2006). Likewise, leveraged buyouts by private equity firms are subject to boom-bust cycles and relatively large portions of debt financing (Kaplan and Strömberg, 2009). Financial markets can also be pro-cyclical when haircuts for securities financing transactions are reduced in good times and increased in bad times (Brunnermeier and Pedersen, 2009). At the turning point of the financial cycle, a small initial shock might trigger a margin and loss spiral that impedes funding and market liquidity. A similar interaction between leverage and funding liquidity also operates in the banking system (Pierret, 2015).

Although the exact form in which a speculative bubble manifests itself might differ each time, the underlying dynamics are the same. Yet, Galbraith (1993) observed dryly:

"What will not be discussed is that speculation itself or the aberrant optimism that lay behind it. Nothing is more remarkable than this: in the aftermath of speculation, the reality will [be] all but ignored.”

We develop a simple model illustrating how debt financing can amplify financial shocks (Schoenmaker and Wierts, 2015). Financial firms' assets $A$ are financed by equity $E$ and debt $D$. Leverage is defined as debt over equity $L=D / E$. Assuming that the nominal value of debt is constant, a change in the value of assets $g_{t}^{a}$ is added as profit to equity $g_{t}^{e}$ :

$$
A_{t}=\left(1+g_{t}^{a}\right) A_{0}=\left(1+g_{t}^{e}\right) E_{0}+D_{0}
$$

where subscript $t$ is for time. Using our definition of leverage gives the following relationship between asset and equity growth:

$$
g_{t}^{e}=g_{t}^{a}\left(1+L_{0}\right)
$$

Next, financial firms have to choose their leverage. Profit maximisation is the key driver behind the financial firms' choice of leverage, subject to maximum desirable risk (risk appetite). Individual firms trade off private return $r e$ versus private risk and do not internalise market failures from high leverage and maturity mismatch. Leverage will amplify the impact of the return difference between assets $r^{a}$ and debt $r^{d}$ on the private return:

$$
r_{t}^{e}=r_{t}^{a}+\left(r_{t}^{a}-r_{t}^{d}\right) L_{t}
$$


The incentive to leverage depends on the difference in the return from assets and debt. ${ }^{2}$ A profit-maximising financial firm will maximise its leverage for a given risk, when asset returns are higher than the cost of debt (asset boom), and vice versa (asset bust). During the upswing of the financial cycle, the return differential is magnified both by rising asset prices and cheap short-term funding (Perotti and Suarez, 2011), so that financial institutions increase profits by expanding balance sheets and building up maturity mismatches. Adrian and Shin (2010) show that US investment banks not only brought leverage back to its initial level through balance-sheet adjustment, but even increased leverage in the run-up to the financial crisis. Similarly, ESRB (2015a) shows that leverage was pro-cyclical in the EU banking system.

In our model, we use the conservative assumption in terms of behavioural response that a profit-maximising financial institution would 'only' bring leverage back to its initial level $L_{0}$. Given that debt has a constant value in nominal terms, the level of debt grows with the same growth rate as the price change in equity:

$$
D_{t}^{b}=\left(1+g_{t}^{e}\right) D_{0}=\left(1+g_{t}^{a}\left(1+L_{0}\right)\right) D_{0}
$$

where superscript $b$ indicates that this is a behavioural response. This produces a second round behavioural effect on assets:

$$
A_{t}^{b}=\left(1+g_{t}^{a}\left(1+L_{0}\right)\right) A_{0}
$$

The ultimate increase of a financial institution's balance sheet thus depends on the growth in asset prices and the level of its initial leverage. Figure 2 illustrates the effect on a financial institution's balance sheet with leverage and feedback effect on asset prices. We assume asset price growth of 2.5 per cent in period 1 , and a moderate feedback effect of 0.1 in each period on the asset price growth rate in the previous period, so that it drops to zero in a few periods and the size of the balance sheet stabilises. Various levels of initial leverage $L_{0}=D_{0} / E_{0}$ are used: $L_{0}=$ $24=96 / 4 ; L_{0}=9=90 / 10 ; L_{0}=4=80 / 20$. We also show the case of no leverage $L_{0}=0$. The balance sheet expands very rapidly for higher levels of initial leverage, but not in the case of no leverage. Note that the example with a high leverage of 24 corresponds to the current situation for banks, in which banks have about 4 per cent equity capital (unweighted) and 96 per cent debt.

Similarly, the balance sheet shrinks during bad times, when the return on assets is below the return on debt.
Figure 2. Balance sheet growth with leverage

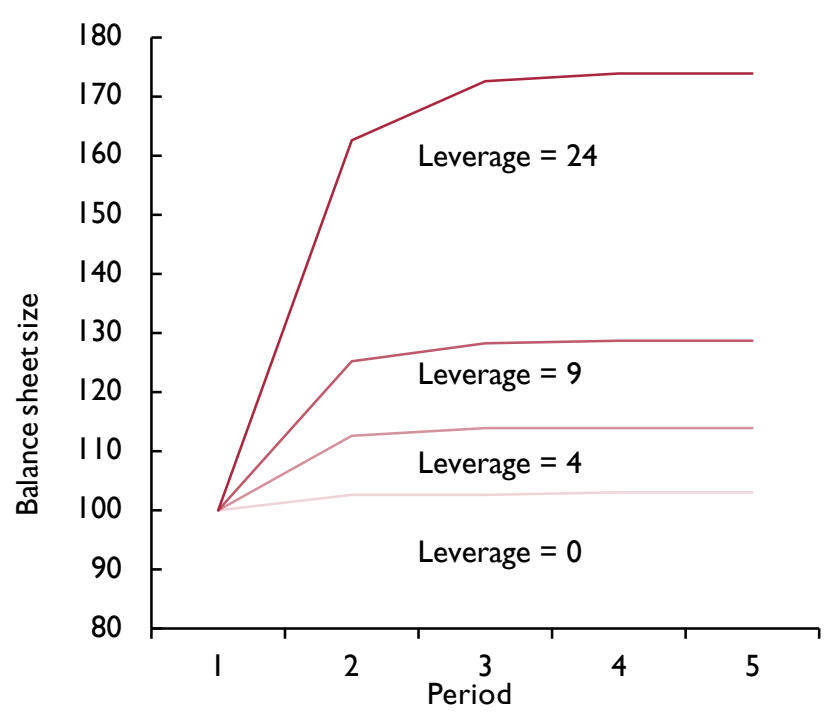

Source: Schoenmaker and Wierts (2015).

Note: Assumed price growth is 2.5 per cent. The feedback effect on asset prices is 0.1 for each simulated leverage $L=D / E=0 ; 4 ; 9 ; 24$.

As the financial institution makes a loss, equity will decrease. To keep leverage constant, the institution has to cut back its debt (for example, by reducing its wholesale funding). This is the infamous process of deleveraging that we experienced in the aftermath of the global financial crisis.

The key take-aways from our simple model are threefold (Schoenmaker and Wierts, 2015). First, modest levels of debt financing might already lead to relatively large expansion of the balance sheets of financial firms in upturns. Second, the feedback loop of asset price shocks on the balance sheet is endogenous. A return differential on assets and debt of 2.5 per cent combined with leverage of 24 (which is common in banking) leads to a 75 per cent expansion of the financial firm's balance sheet. Third, for higher initial leverage, the policy adjustment would need to be stronger to constrain excessive balance-sheet growth at financial institutions (note that the asset side of financial institutions' balance sheets approximates the provision of finance - predominantly credit - to the private sector). Restricting maximum permissible leverage would dampen amplification of the financial cycle, as we discuss in Section 4.

Our model with profit-maximising financial institutions driving leverage fits in a new strand of models on 
countercyclical macroprudential policy. Aikman et al. (2015) develop a slightly different model, in which risk taking is driven by reputational concerns. Banks have an incentive to produce high returns - if necessary by excessive risk-taking - when other banks announce high returns. They call this the 'keeping up with the Goldmans' effect. The result of their model is similar, a credit cycle with large amplifications. Acharya and Naqvi (2012) show that volume-based compensation for loan officers induces excessive risk-taking and credit creation. Gersbach and Rochet (2014) find that banks allocate too much borrowing capacity to good states and too little to bad states, because bankers aim to maximise their rents from lending, taking capital prices and prices of financial assets as given.

\subsection{Macroprudential supervision in the Euro Area}

Special considerations apply to the Euro Area in the presence of the monetary and banking union. Macroprudential policy is even more important in a monetary union. With a 'one-size-fits-all' monetary policy, proactive macroprudential policies are needed to address financial imbalances at the country level. While there is clear evidence that the financial cycles differ at the country level (Merler, 2015), there is no consensus on the appropriate level of coordination. Figure 3 depicts the current division of powers. In monetary and supervisory policy, the European Central Bank (ECB) takes the lead with some contributing role for national central banks (NCBs) and national competent authorities (NCAs). In contrast, in macroprudential policy the NCAs have the first say, with the ECB in a secondary role.

Sapir (2014) and Schoenmaker (2014) argue for a strong role for the ECB. If too much is left to the national level, emerging financial imbalances might go unchecked in some countries. There is also a risk of inconsistent application of macroprudential tools, while there are strong cross-border stability effects within a

Figure 3. Policy framework for the Euro Area

\begin{tabular}{lll} 
Union & Dimension & Major players \\
Monetary union & Monetary & ECB with NCBs \\
\cline { 2 - 3 } & Macro & NCAs with ECB \\
Manking union & ECB with NCAs
\end{tabular}

Source: Schoenmaker (20I4). monetary and banking union. Finally, a consistent policy framework for a broader financial union suggests the alignment of the various policy tools at the same level.

\section{Measuring financial imbalances}

The global financial crisis has reminded us that we need to include financial sector variables in macroeconomic analysis (e.g. Drehmann et al., 2012; Borio, 2014a). The so-called financial cycle, which measures financial imbalances, is a key input for defining the macroprudential policy stance. The regular publication of the financial cycle will visually raise the awareness of policymakers. We propose to start central banks' financial stability reviews with an update of the financial cycle, just as the monetary report starts with the inflation outlook. While the latter is on a monthly or quarterly basis, financial cycle dynamics are more prolonged (see below). The update could therefore follow the biannual rhythm of the financial stability review.

Section 3.1 discusses the choice of indicators, an important methodological issue, and the relationship with the business cycle. Section 3.2 shows the current financial cycles across the Euro Area, illustrating major divergence between counties.

\section{I How to measure the financial cycle?}

Which financial indicators can be used to measure the financial cycle? On the one hand, you might want to extract as much information from financial variables as possible, which is a paradise for econometricians. On the other hand, you might want to keep the number of variables as parsimonious as possible. Moreover, the choice of a few key variables, which are easily understandable, aids the policy process. It helps when policymakers understand which variables are driving the financial cycle, instead of deriving the financial cycle as an outcome from an abstract, statistical, analysis.

In a historical survey covering 1870 to 2008 , Schularick and Taylor (2012) showed that cyclical fluctuations in credit are at the heart of the boom-bust cycle. The next question is which assets are financed by these episodes of credit expansion (and subsequent contraction). In followup work, Jorda, Schularick and Taylor (2015) studied bubbles in housing and equity markets over the past 140 years in seventeen countries. They demonstrate that what makes some bubbles more dangerous than others is credit. When fuelled by credit booms, asset price bubbles increase financial crisis risks; upon collapse they tend to be followed by deeper recessions and slower recoveries. Credit-financed house price bubbles have emerged as a particularly dangerous phenomenon. These findings are 
consistent with earlier work by Reinhart and Rogoff (2009) and Claessens et al. (2014), who also show that the vast majority of banking crises are related to house price cycles.

Credit booms fuel house prices and increase the leverage of borrowers (in particular households). This leaves households vulnerable to declines in house prices and tightening of credit conditions. When the correction occurs, households run into debt servicing problems, which cause reductions in consumption negatively impacting on economic growth as well as payment arrears on mortgages or foreclosures leading to systemic risks in the financial system.

Drehmann et al. (2012) also found that credit and property prices tend to co-vary rather closely with each other, especially at low frequencies, confirming the importance of credit in the financing of construction and the purchase of property. In addition, the variability in the two series is dominated by the lowfrequency components. By contrast, equity prices can be a distraction. They co-vary with the other two series far less. And much of their variability concentrates at comparatively higher frequencies. Claessens et al. (2011) investigate credit, housing and equity cycles. They also report strong co-movements in credit and housing cycles. Credit cycles accompanied by housing cycles typically last longer and are more pronounced. Next, Claessens et al. (2011) find that signals from equity cycles are noisy, as these are shorter-lived and coincide less with financial crises.

Schüler et al. (2015) include equity and bond prices in addition to credit and property assets. They conclude that their composite financial cycle performs better at predicting financial crises than single or bivariate composed indicators. Nevertheless, Schüler et al. (2015) also find that credit and house prices are characterised by medium-term cycles, while equity and bond prices have important fluctuations both at medium and shortterm cycle frequencies. ${ }^{3}$

Finally, Borio (2014a) characterises the financial cycle in relation to the business cycle. First, the financial cycle has a stronger amplitude. Borio (2014a) finds that the financial cycle has a five times greater amplitude than the business cycle. Next, Borio (2014a) reports an average length of sixteen years, while Schüler et al. (2015) find a length of 7.2 years. While the exact length may differ in different studies, they all indicate that the average length is longer than that of the business cycle. This reinforces the earlier argument that the financial cycle can be qualified as a medium-term phenomenon, which is best captured by credit and property prices that also have a medium-term frequency. Figure 4 illustrates the differences in the business and financial cycles in the US for the 1970-2013 period.

Figure 4. The business and financial cycle in the US (1970-2013)

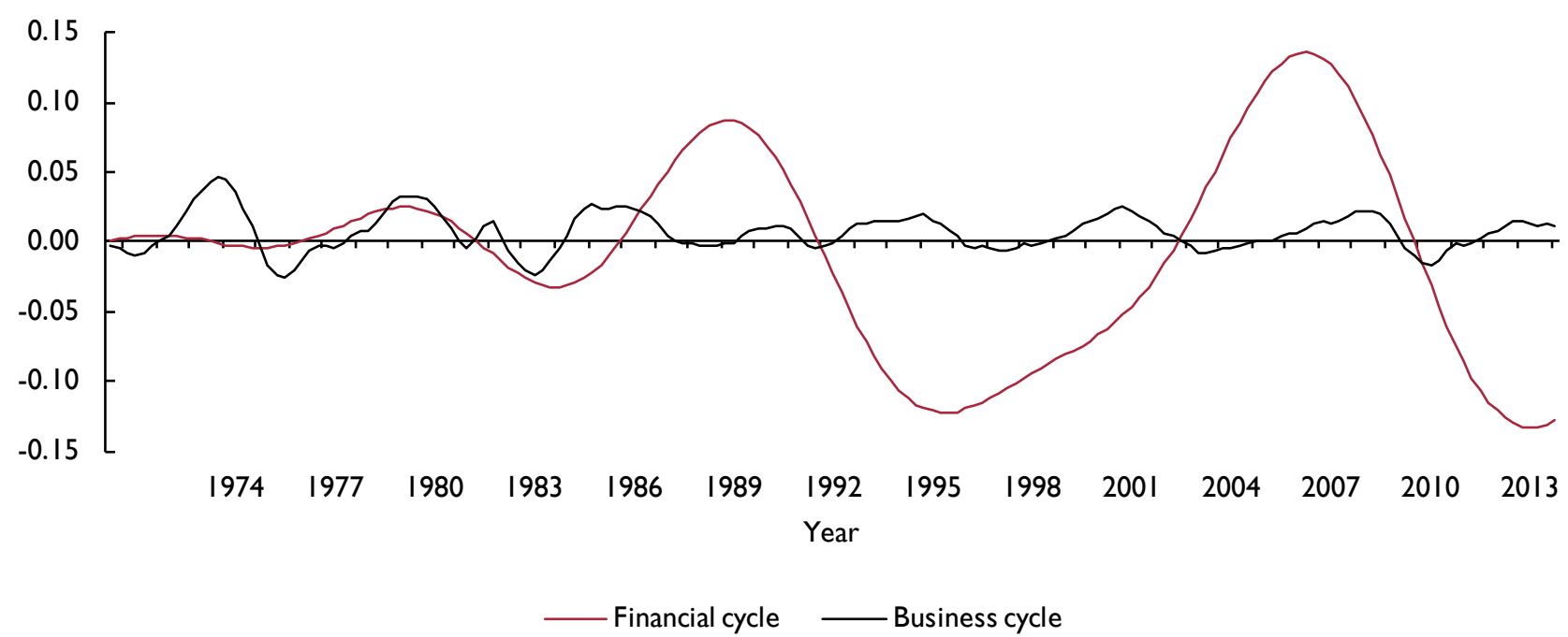

Source: Adapted from Borio (2014a).

Note: The red line traces the financial cycle measured by the combined behaviour of the component series (credit, the credit to GDP ratio and house prices). The black line traces the GDP cycle. 
In sum, a range of indicators has been proposed in the literature, ranging from credit as a key variable (e.g. Schularick and Taylor, 2012; Aikman et al., 2015), to credit and property prices (e.g. Claessens et al., 2011; Drehmann et al., 2012; Borio, 2014a) and credit, property, equity and bond prices (e.g. Schüler et al., 2015). But while preferences differ on parsimonious versus complex methods, all authors appear to agree on the relevance of including credit and property prices. These variables should not be read as indicators for where the next crisis will come from, but as a general measurement of financial imbalances which makes the economy crisis-prone in the Minsky sense.

\subsection{The financial cycle in the Euro Area}

Moving to Europe, we are interested to see the behaviour of the financial cycle in the Euro Area. Do the aggregate and country cycles move in tandem? Merler (2015) investigates the financial cycle, based on the variance of credit growth and real house price growth, for the period from 1971 till 2014. Figure 5 illustrates the aggregate financial cycle for the Euro Area and its sub-regions. The North comprises Germany and the Netherlands. The Centre encompasses France and Italy. The South consists of Ireland and Spain. Figure 5 clearly shows that financial cycles have differed across the Euro Area since the late 1990s, the start of the euro. The single monetary policy might have contributed to the divergence of the financial cycle.

Another interesting finding is that the periphery countries in the 'South' faced a strong expansion ahead of the global financial crisis, which started in 2007, while the aggregate Euro Area cycle is more moderate (Merler, 2015). This reinforces the point that macroprudential policy needs to be applied at country level across Europe. Importantly, if a countercyclical macroprudential policy had been in place at the start of the euro, this might have dampened the financial cycle in the periphery countries (Jiménez et al., 2015). But we do not know the counterfactual, of course. Nevertheless, figure 5 strongly suggests that countercyclical macroprudential instruments are very useful and need to be differentiated across countries.

Figure 6, also taken from Merler (2015), shows the financial cycle for the six countries. Panel $C$ for Spain and Ireland shows that the introduction of the euro seemed to coincide with the start of a big expansion phase in the financial cycle. In Ireland, there was a temporary downturn related to the dot-com bubble burst, but it was quickly reverted into an expansion phase. In Germany

Figure 5. Financial cycle in the Euro Area

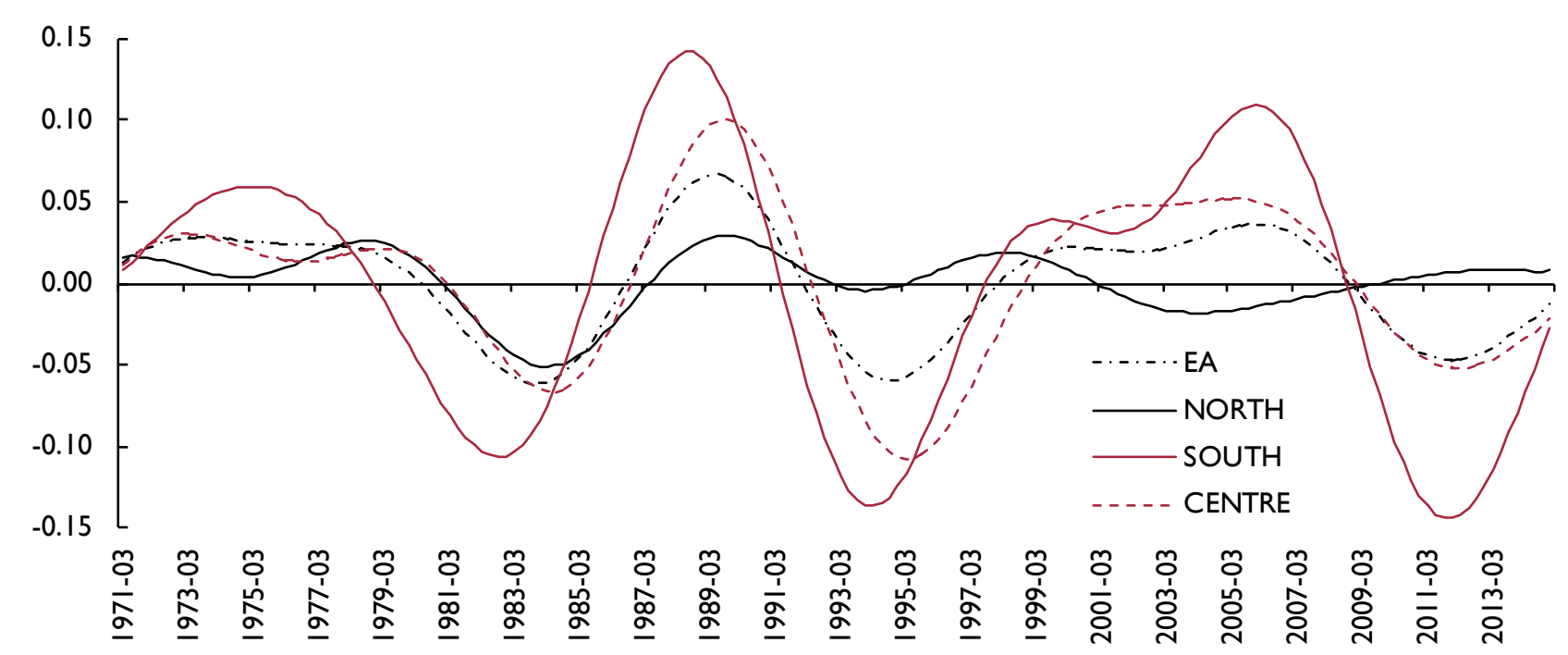

Source: Merler (2015)

Note: The financial cycle is based on credit growth and growth in real house prices. A band-pass filter is applied to isolate specifically medium-term cycles, defined as cycles in real credit growth or real house prices with duration between 8 and 30 years. The information from these two cycles is eventually combined into a summary indicator, by means of principal component analysis. EA is the Euro Area; North is Germany and the Netherlands; Centre is France and Italy; South is Spain and Ireland. 
Figure 6. Financial cycles - individual countries (black lines) vs Euro Area (red line)

\section{Panel A. North}

\section{Germany}

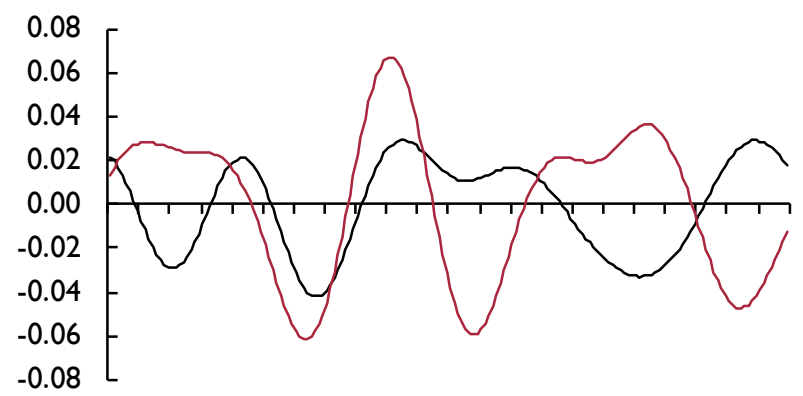

ñ

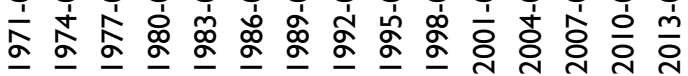

Netherlands

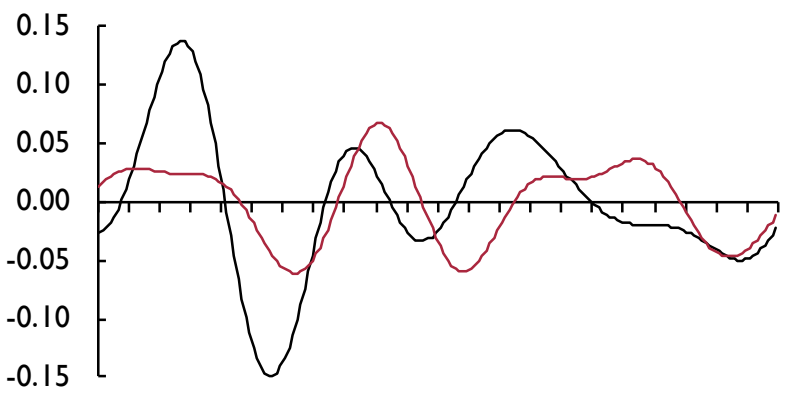

๓

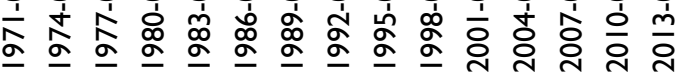

\section{Panel B. The Centre}

France

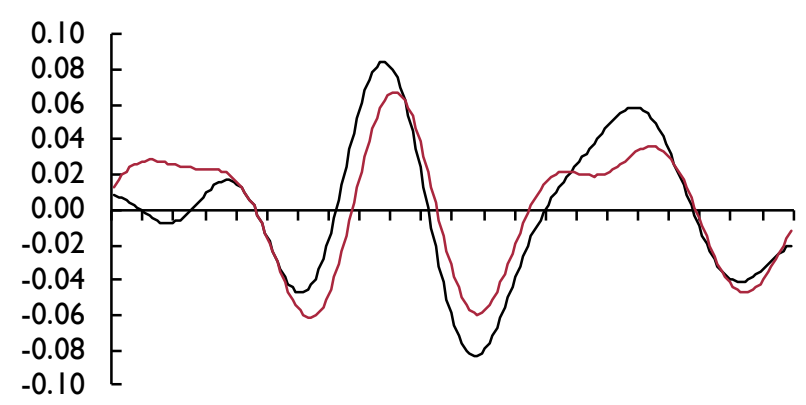

mố

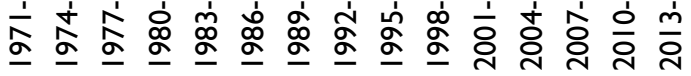

Italy

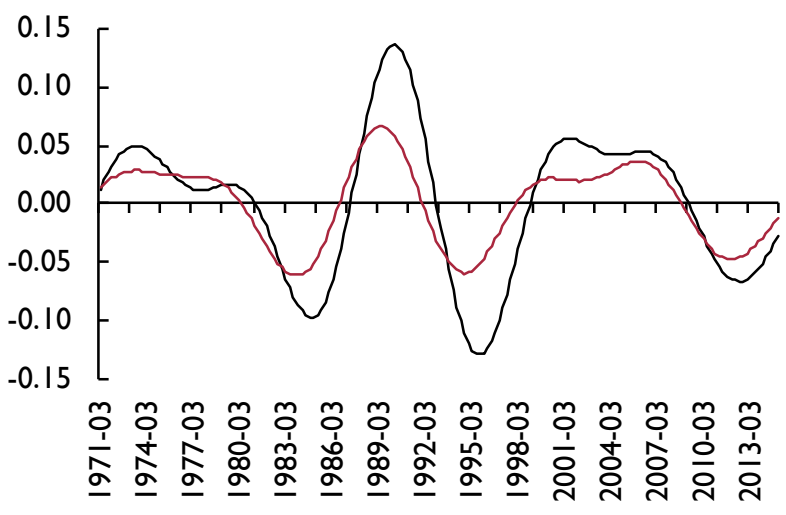

Panel C. The South

Spain

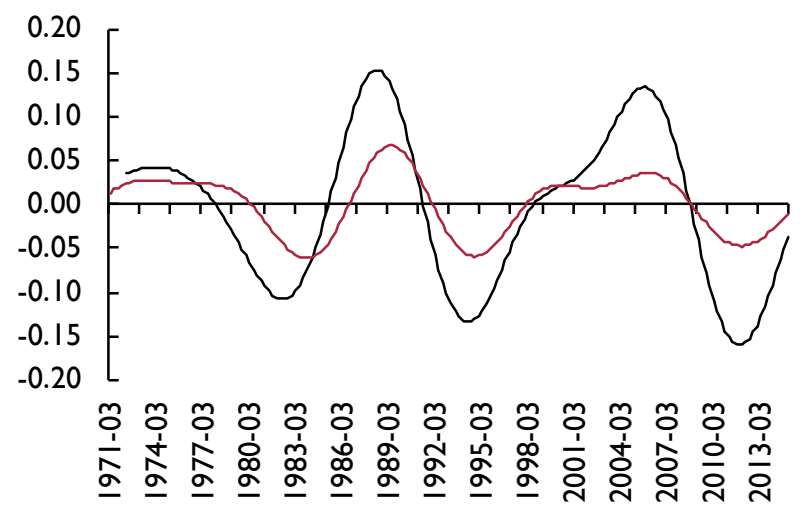

Ireland

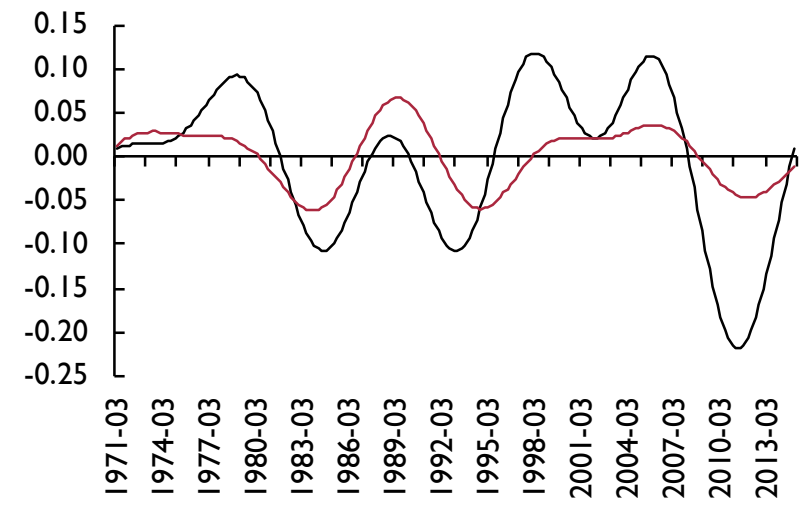

Source: Merler (2015).

Note: See Figure 5. 
and the Netherlands (Panel A), the opposite happened, and both countries entered a contraction phase in the late 1990s. Contraction lasted till 2010 in Germany and longer in the Netherlands. Finally, Panel B indicates that France and Italy instead moved very closely to the Euro Area financial cycle.

Figures 5 and 6 illustrate the power of visual presentation. Regular reporting in the ECB Financial Stability Review of the unfolding financial cycles in the participating countries might have alerted policymakers. The next step is an appropriate instrument to curb the cycle.

\section{Policy}

The Tinbergen Rule suggests that we need a new instrument separate from monetary policy for financial stability purposes. While the underlying mechanism of amplification of the financial cycle through leverage in Section 2 is general, macroprudential policy instruments are developed in silos (Schoenmaker and Wierts, 2015). The Basel policy response with a countercyclical capital buffer and a leverage ratio is only directed at banks. By contrast, loan-to-value (LTV) ratios are borrower-based and can be designed so that they apply to all financial institutions that grant mortgages. ${ }^{4}$ But sectoral regulations intensify the boundary problem (Goodhart, 2008). When regulation for one sector is tightened, business will shift to other sectors with less or no requirements. Cizel et al. (2015) find evidence for the cross-sector substitution effects of macroprudential policy.

An important question is whether macroprudential policy should address a financial boom that is concentrated in a particular sector or an economy wide financial boom. Wherever possible, a specific macroprudential instrument to address the build-up of imbalances in a particular sector is preferable. But the model and subsequent analysis in this paper is concerned with general financial imbalances, in the spirit of Minsky (1986). As credit becomes more easily available in the upswing of the financial cycle, financial imbalances are building up across the economy. A sector-by-sector approach may then miss some segments or induce migration of activities, especially to newly emerging segments such as securitisation of sub-prime mortgages in the run-up to the global financial crisis. In a similar vein, monetary policy follows a general approach in curbing the consumer price index instead of the prices of particular consumption goods.

There are several proposals for countercyclical macroprudential policy instruments to curb the financial cycle. Gersbach (2011) proposes a leverage ratio for the banking system to moderate credit cycles and to reduce the likelihood of financial crises. His banking systemwide leverage ratio is defined as;

- total equity in the banking sector (held by non-banks) to

- total end-borrower lending (loans to non-financial firms, households, and governments), plus other nonbank assets.

As the system leverage ratio applies to the banking system as a whole, the leverage ratios for individual banks can differ according to their risk profile. An interesting feature is that Gersbach's system leverage ratio is really a macro instrument, which can be used in a time-varying manner. The aggregate leverage ratio for the next period, for example, depends on the ratio that is currently set, the state of money and credit, and on current vulnerabilities of the banking system (Gersbach, 2011). While it is impossible to specify a fixed formula for determining the aggregate leverage ratio, Gersbach stresses that it is essential that such policies are as systematic, transparent and accountable as traditional monetary policy rules.

More generally, several authors have studied the appropriate design of countercyclical capital buffers, as currently employed in the Basel 3 capital adequacy framework (see, for example, Drehman et al., 2011; Gersbach and Rochet, 2014). Aikman et al. (2015) propose to apply anti-cyclical capital and liquidity requirements or to tie remuneration packages to longterm performance to curb the credit cycle. Importantly, the latter authors argue that these instruments should be applied across borders and sectors to prevent crossborder and cross-sector leakages.

\section{I A common leverage ratio across the financial system ${ }^{5}$}

We have proposed a countercyclical (i.e. time-varying) leverage ratio to dampen the endogenous feedback loops in credit growth (and decline) and thus stabilise the financial cycle (Schoenmaker and Wierts, 2015). This instrument is designed in the spirit of Gersbach (2011), but applied to individual financial institutions and their transactions. This new framework differs from the traditional view on regulation of equity as a buffer against unexpected losses caused by exogenous shocks. Whereas the 'buffer view' can only motivate relatively small capital buffers, our new framework calls for much lower levels of leverage in the system to constrain excessive credit growth. 
As discussed earlier, an integrated approach to regulate leverage is necessary to stabilise the financial cycle across the financial system. We therefore start with harmonising the terminology on leverage (Schoenmaker and Wierts, 2015). Under the Basel 3 capital requirements, the leverage ratio for banks is:

$$
L R=\frac{\text { Equity }}{\text { Total exposure }}
$$

The leverage ratio can be applied to any type of financial institution, such as banks, special purpose vehicles (SPVs), or hedge funds. It can also be applied to collateralised transactions of different entities, such as securities financing transactions (e.g. repos) or mortgages. As the value of assets can vary depending on credit and market risk, the transaction is typically 'overcollateralised', whereby more assets are provided than the underlying loan (debt). This excess is called a haircut:

$$
\text { Haircut }=\frac{(\text { Assets } * \text { price })-\text { Debt }}{\text { Assets } * \text { price }}=\frac{\text { Equity }}{\text { Assets } * \text { price }}
$$

Finally, a typical indicator used in housing finance is the loan-to-value ratio:

$$
L T V=\frac{\text { Debt }}{\text { Asset } * \text { price }}
$$

Comparing the different yardsticks for leverage, we get $L R=$ Haircut $=1-L T V$. Following Basel 3, we propose to use the leverage ratio, which is defined as a minimum equity requirement, as the basis for a system-wide regulatory leverage requirement. This common leverage ratio is equivalent to a maximum debt requirement to constrain credit.

Microprudential regulation attunes the leverage ratio for each (regulated) segment to the underlying risk for an individual institution or market. We observe a wide range of leverage ratios across the financial system from 1 per cent for special purpose vehicles to 20 per cent for mortgages (Schoenmaker and Wierts, 2015). We introduce our minimum common leverage ratio to stabilise the financial cycle. This macroprudential requirement should override microprudential requirements, as the former internalises the endogenous effects of leverage (Brunnermeier and Sannikov, 2014). Again in the spirit of Gersbach (2011), the countercyclical application of our common leverage ratio depends on the state of credit, i.e. where we are in the financial cycle. In the upswing, the common leverage ratio will be increased to slow down credit growth, while in the downswing, the ratio will be decreased to stimulate credit growth.

In Schoenmaker and Wierts (2015), we illustrate the working of the common leverage ratio with a hypothetical example of a minimum leverage ratio requirement of 10 per cent at the macro level applied to debt-based financing across the financial system (which is equivalent to leverage of 9 in figure 2). This 10 per cent would then serve as a minimum across all debt-financed segments of the financial system, mitigating the boundary problem. In individual segments, the minimum leverage ratio could be higher if and when micro considerations require a higher minimum requirement.

\subsection{What would change in practice?}

Market failures and systemic risk are not unique to regulated banking. Examples include: the near collapse of hedge fund LTCM in 1998 because of excessive leverage; market-based finance and securitisation in the run-up to the financial crisis, which exacerbated the upswing of the financial cycle; the default of Lehman, a highly leveraged investment bank; the run on money market funds because of maturity mismatch (i.e. the perception of a nominally stable net asset value); and pro-cyclicality in the repo market (Gorton and Metrick, 2012). At the same time, macroprudential instruments have until now mostly been applied to banks, causing substitution effects (Cizel et al., 2015). What would be the practical implications of our proposed system-wide application of the leverage ratio?

Table 1 summarises existing instruments and ongoing discussions on the regulation of leverage. The message is that limits on leverage already exist for banks, investment funds and residential real estate. And extensions are under discussion, e.g. margin requirements for collateralised derivatives and securities financing transactions. But the instrument has not yet been developed from a holistic perspective: a common minimum while allowing for country- and sector-specific calibrations, to address differences in financial cycles across countries and sector-specific risks such as those related to real estate.

The first step is to compare definitions and to make them consistent, including on the impact of derivatives on synthetic leverage both for banks and investment funds (ECB, 2015a). A holistic approach to minimum haircuts and margins in both centrally- and non-centrally cleared transactions should be developed (ESRB, 2015b). And leverage requirements for Alternative Investment Funds 
Table I. Macroprudential instruments for regulating leverage

\begin{tabular}{|c|c|c|c|c|}
\hline \multirow{2}{*}{ Regulated } & \multicolumn{2}{|l|}{ Entities } & \multicolumn{2}{|c|}{$\begin{array}{l}\text { Transactions by entity } \\
\text { (collateralised financing) }\end{array}$} \\
\hline & Banks & Investment funds & Real estate transactions & $\begin{array}{l}\text { Derivatives and securities } \\
\text { financing transactions }\end{array}$ \\
\hline Regulation & $\begin{array}{l}\text { EU:CRR/CRD IV: } \\
\text { Minimum leverage } \\
\text { ratio } \\
\text { Under discussion } \\
\text { Macroprudential } \\
\text { use of the leverage } \\
\text { ratio - aligning it with } \\
\text { the countercyclical } \\
\text { capital buffer } \\
\text { (ESRB, 20I5a) }\end{array}$ & $\begin{array}{l}\text { EU: alternative } \\
\text { investment funds } \\
\text { (AIFMD) } \\
\text { Option to impose } \\
\text { leverage } \\
\text { requirements } \\
\text { EU:UCITS: } \\
\text { Borrowing up to } \\
10 \% \text { of assets allowed } \\
\text { for temporary } \\
\text { purposes }\end{array}$ & $\begin{array}{l}\text { National legislation: } \\
\text { LTV/LTI caps for } \\
\text { residential real estate } \\
\text { Under discussion: } \\
\text { LTV/LTI limits for } \\
\text { commercial real estate }\end{array}$ & $\begin{array}{l}\text { Under discussion: } \\
\text { Minimum or countercyclical margin } \\
\text { and haircut requirements for } \\
\text { centrally cleared transactions (ESRB, } \\
20 I 5 b \text { ) and non-centrally cleared } \\
\text { transactions (BCBS-IOSCO, } 2015 \text {; } \\
\text { FSB, 20I4).(a) Application should } \\
\text { be to counterparties at transaction } \\
\text { level, independent of how they are } \\
\text { cleared (ECB, 20I5b) }\end{array}$ \\
\hline
\end{tabular}

Note: (a) Both EMIR and the draft Securities Financing Transactions Regulation do not at this stage provide for macroprudential use of margin and haircuts by authorities. EMIR does however contain minimum standards for CCPs that aim at addressing pro-cyclicality (ESRB, 20I5b).

- including hedge funds and private equity - should be made operational given that the legal base has been created already. All this would allow for initial discussions on the top-down calibration of all instruments together.

The second step is to analyse the interaction between leverage requirements, including possible gaps and overlaps. On gaps, for example, some countries have recently started to apply monitoring requirements on 'non-securitisation' SPVs. On possible overlaps, for example, the imposition of leverage requirements on the banking sector sparked a discussion about its effects on banks' securities and financing transactions, i.e. their possible migration to less-regulated entities. Likewise, the combination of a leverage requirement on banks with an LTV limit for their borrowers might lead to the migration of mortgage financing to less-regulated nonbanks. This could be seen as a desirable side effect, as Europe suffers from a bank bias that increases systemic risks and reduces economic growth (Langfield and Pagano, 2016). But the point is that policymakers should be in a position to take a holistic view on introducing and withdrawing such incentives.

The third step is to incorporate the new instrument consistently in legislation. The European Commission is responsible for proposing financial sector regulation in the EU/EEA. As the Commission follows a sectoral approach, the directives and/or regulations for the various debt-financed sectors might need to be adapted and extended with a macroprudential section. As indicated, several segments are already subject to the possibility of regulation on leverage, such as banks under the Capital Requirements Regulation and Directive (CRR/CRD IV) and hedge funds and private equity under the socalled Alternative Investment Fund Managers Directive (AIFMD). Whereas the authorities can already adjust leverage requirements for alternative investment funds to address systemic risk, similar provisions are under discussion for the banking sector (ESRB, 2015a). Next, securities and derivative transactions are subject to margin calls or haircuts under the European Market Infrastructure Regulation (EMIR). These rules should be adapted to provide the authorities with the power to allow for a common and countercyclical application (ESRB, 2015b, ECB, 2015b). Importantly, ECB (2015b) argues that these tools should be applied to counterparties at transaction level so that all relevant transactions are within scope, irrespective of how they are cleared. This would mimic our preferred legal design for LTV/LTI caps and create a consistent legal approach (table 1).

On the institutional side, the European Systemic Risk Board (ESRB) should be given an advisory role on the application of the common leverage ratio, as the ESRB is responsible for monitoring systemic risk across the EU and making recommendations when it identifies systemic threats. A building up of financial imbalances that are unsustainable would qualify as such a threat.

Moving to execution, the respective central banks - in their capacity as macroprudential authorities - need to get 
the powers in the newly drafted macroprudential sections of the above-mentioned directives and regulations to apply the countercyclical instrument, independent of politicians. The execution of macroprudential policy is, just as monetary policy, subject to pressures from the election cycle. Moreover, these powers should also allow for a macro application of the instrument with a view to financial stability.

As suggested in Section 2, the ECB should under the Single Supervisory Mechanism (SSM) become responsible for the consistent application of macroprudential instruments within the Euro Area and internalisation of cross-border effects. The ECB would also be able to assess the tradeoffs between the different financial policies - monetary, macroprudential and microprudential - at the same level, just like the Bank of England in the United Kingdom. ${ }^{6}$ While the NCBs are necessary to provide input on the financial conditions in their respective financial systems, the ECB should therefore in conjunction with the NCBs have the power to set the minimum countercyclical leverage ratio. The leverage ratio could then be differentiated across countries, because the financial cycle differs between them.

\section{Conclusions}

There has been much debate on the need for macroprudential policy in the aftermath of the global financial crisis. Academics and policymakers have advanced various theories and models, but a consensus on the right approach has not yet emerged. Nevertheless, we call the central banking community to arms. The current monetary policy stance of quantitative easing might be needed to avert potential deflationary drifts and stimulate subdued growth, the risk of financial booms is increasing as the BIS has repeatedly warned. In the Tinbergen tradition, we propose a separate instrument to constrain excessive credit growth. The good news is that central banks are starting to measure and publish the financial cycle, which provides the necessary input for determining the macroprudential policy stance.

While there is an emerging consensus that countercyclical capital ratios are helpful, there is widespread doubt that the current 2.5 per cent countercyclical buffer as part of the risk-weighted capital ratio will suffice to break a fullblown credit cycle. With an average risk weight of less than 40 per cent, the 2.5 per cent risk-weighted buffer translates to a countercyclical leverage buffer of less than 1 per cent. Simulations indicate that a countercyclical leverage buffer of up to 2 per cent is more appropriate to dampen an asset price shock (Schoenmaker and Wierts, 2015).
We therefore propose a bold approach based on the leverage ratio. Bold because the range of appropriate leverage ratios to constrain the financial cycle is likely to go beyond the current leverage ratio of 3 per cent. We recommend starting calibrations on an appropriate range for the leverage ratio. Our proposal is also bold because the common leverage ratio should be applied across all parts of the financial system that are highly leveraged. As banks are deleveraging, non-bank credit is growing. This warrants a system-wide approach to constrain excessive credit growth.

To stimulate (bold) action, we would like to leave the reader with a final thought. Policymakers and academics (including ourselves) love to read again and quote the classics such as Galbraith (1993) and Kindleberger and Aliber (2011) after each financial crisis. Some more attention to them in the upswing of the financial cycle might, hopefully, reduce future citations.

\section{NOTES}

I This section draws partly upon the introduction of a VoxEU book on Macroprudentialism (Schoenmaker, 2014).

2 As banks' assets have a longer maturity than debt, leverage interacts with maturity mismatch. If short-term funding markets are liquid and term-premia are positive, leverage and maturity transformation are likely to go hand-in-hand.

3 Bond yields are also relevant for the shorter frequency business cycles, which are analysed for monetary policy purposes. In order to keep monetary and macroprudential policies separate, authorities may choose not to include bond yields in the financial cycle.

4 However, LTV caps have mostly been applied to banks in practice (Cizel et al., 2015).

5 This sub-section draws upon Schoenmaker and Wierts (20I5).

6 The combination of all these financial policies would lead to a concentration of powers. Appropriate transparency and accountability mechanisms are important.

\section{REFERENCES}

Acharya, V. and Naqvi, H. (20I2), 'The seeds of a crisis: a theory of bank liquidity and risk-taking over the business cycle', Journal of Financial Economics, 106, Pp. 349-66.

Adrian, T. and Shin, H. (2010), 'Liquidity and leverage', Journal of Financial Intermediation, 19, pp. 4I8-37.

Advisory Scientific Committee (ASC) (2014), Allocating MacroPrudential Powers, Report No. 5 of the Advisory Scientific Committee of the European Systemic Risk Board.

Aikman, D., Haldane, A. and Nelson, B. (20I5), 'Curbing the credit cycle', The Economic Journal, I25, pp. 1072-109.

Almeida, H., Campello, M. and Liu, C. (2006), 'The financial accelerator: evidence from international housing markets', Review of Finance, 10, pp. 321-52.

Baker, A. (2013), 'The new political economy of the macroprudential ideational shift', New Political Economy, 18, pp. I I 2-39.

Barth, J. and Wihlborg, C. (20I6), 'Too big to fail and too big to save: dilemmas for banking reform', National Institute Economic Review, 235, February. 
BCBS-IOSCO (20I5), Margin Requirements for Non-Centrally Cleared Derivatives, Basel.

Borio, C. (20|4a), 'The financial cycle and macroeconomics: what have we learnt?', Journal of Banking and Finance, 45, pp. I82-98.

-(20|4b), '(Too) great expectations for macro-prudential?', Central Banking Journal, 4I, pp. 79-85.

Brunnermeier, M., Crockett, A.,Goodhart, C., Persaud, A. and Shin, H. (2009), 'The fundamental principles of financial regulation', Geneva Report on the World Economy, vol. I I. CEPR, London.

Brunnermeier, M. and Pedersen, L. (2009), 'Market liquidity and funding liquidity', Review of Financial Studies, 22, pp. 220I-38.

Brunnermeier, M. and Sannikov, Y. (20I4), 'A macroeconomic model with a financial sector', American Economic Review, 104, PP. 379-42I.

Cizel, J., Frost, J., Houben, A. and Wierts, P. (2015), 'Effective macroprudential policy: cross-sector substitution of price and quantity measures', IMF Working Paper.

Claessens, S., Kose, M., Laeven, L. and Valencia, F. (2014), Financial Crises: Causes, Consequences, and Policy Responses, Washington DC: IMF.

Claessens, S., Kose, M. and Terrone, M. (20II), 'Financial cycles: what? how? when?', in Clarida, R. and Giavazzi, F. (eds), NBER International Seminar in Macroeconomics 2010, pp. 303-43.

Danielsson, J. (2013), Global Financial Systems: Stability and Risk, Harlow: Pearson.

Drehmann, M., Borio, C. and Tsatsaronis, K. (20II), 'Anchoring countercyclical capital buffers: the role of credit aggregates', International Journal of Central Banking, 7, pp. I89-239.

-(20I2), 'Characterising the financial cycle: don't lose sight of the medium term!', BIS Working Papers, No. 380.

ECB (20I5a), 'Synthetic leverage in the investment fund sector', Financial Stability Review, Frankfurt: ECB.

-(20I5b), ECB response to the European Commission's consultation on the review of the European Market Infrastructure Regulation (EMIR), Frankfurt: ECB.

ESRB (20I5a), Handbook on the Macro-prudential Use of the Leverage Ratio, Frankfurt: European Systemic Risk Board.

-(20I5b), ESRB Report on the Efficiency of Margining Requirements to Limit Pro-Cyclicality and the Need to Define Additional Intervention in this Policy Area, Frankfurt: European Systemic Risk Board'

FSB (20 I4), Strengthening Oversight and Regulation of Shadow Banking - Regulatory Framework for Haircuts on Non-centrally Cleared Securities Financing Transactions, Basel: FSB.

Galati, G. and Moessner, R. (2013), 'Macroprudential policy - a literature review', Journal of Economic Surveys, 27, pp. 846-78.

-(20I4), 'What do we know about the effects of macroprudential policy?', DNB Working Paper, No 440.

Galbraith, J.K. (1993), A Short History of Financial Euphoria, New York: Viking Penguin.

Geanakoplos, J. (20I0), 'The leverage cycle', in Acemoglu, D., Rogoff, K. and Woodford, M. (eds), NBER Macroeconomic Annual 2009, 24 , pp. I-65.

Gersbach, H. (20II), 'A framework for two macro policy instruments: money and banking combined', CEPR Policy Insight No. 58.

Gersbach, H. and Rochet, J.-Ch. (2014), 'Capital regulation and credit fluctuations', Working Paper, UZH and ETH Zurich.

Goodhart, C. (2008), 'The boundary problem in financial regulation', National Institute Economic Review, 206, pp. 48-55.

- (20II), 'The changing role of central banks', Financial History Review, 18, pp. 135-54.

-(20I4), 'The use of macroprudential instruments', in Schoenmaker, D. (ed.), Macroprudentialism, London: CEPR, VoxEU eBook, pp.
II-20.

Gorton, G. and Metrick, A. (20I2), 'Securitised banking and the run on repo', Journal of Financial Economics, I02, PP. 435-5I.

Hanson, S., Kashyap, A. and Stein, J. (20II), 'A macroprudential approach to financial regulation', Journal of Economic Perspectives, 25, pp. 3-28.

Jiménez, G., Ongena, S., Peydro, J.L. and Saurina Salas, J. (20I5), 'Macroprudential policy, countercyclical bank capital buffers and credit supply: evidence from the Spanish dynamic provisioning experiments', Working Paper, available at http://ssrn.com/ abstract $=2049284$.

Jorda, O., Schularick, M. and Taylor, A. (2015) 'Leveraged bubbles', Journal of Monetary Economics, online 15 September.

Kaplan, S.N. and Strömberg, P. (2009), 'Leveraged buyouts and private equity, Journal of Economic Perspectives, 23, pp. I2I-46.

Kindleberger, C. and Aliber, R. (20I I), Manias, Panics and Crashes: A History of Financial Crises, Sixth Edition, Basingstoke: Palgrave Macmillan.

Kiyotaki, N. and Moore, J. (1997), 'Credit cycles', Journal of Political Economy, 105, pp. 21I-48.

Langfield, S. and Pagano, M. (20I6), 'Bank bias in Europe: effects on systemic risk and growth, Economic Policy (forthcoming).

Merler, S. (20I5), 'Squaring the cycle: financial cycles, capital flows and macroprudential policy, Bruegel Working Paper No. 2015/I4, Brussels.

Minsky, H. (1986), Stabilizing an Unstable Economy, Yale University Press.

Perotti, E. and Suarez, J. (20I I), 'A Pigovian approach to liquidity regulation', International Journal of Central Banking, 7(4), pp. 3-4I.

Pierret, D. (2015), 'Systemic risk and the solvency-liquidity nexus of banks', International Journal of Central Banking, I I (3), pp. 193-227.

Reinhart, C. and Rogoff, K. (2009), This Time Is Different: Eight Centuries of Financial Folly, Princeton: Princeton University Press.

Sapir, A. (20/4), 'Europe's macroprudential policy framework in light of the banking union', in Schoenmaker, D. (ed.), Macroprudentialism, London, CEPR: VoxEU eBook, PP. I6I-70.

Schoenmaker, D. (20I4), Macroprudentialism, London, CEPR, VoxEU eBook.

Schoenmaker, D. and Kremers, J. (2014), 'Financial stability and proper business conduct: can supervisory structure help to achieve these objectives?', in Huang, R. and Schoenmaker, D. (eds), Institutional Structure of Financial Regulation: Theories and International Experiences, London: Routledge, Pp. 29-39.

Schoenmaker, D. and Wierts, P. (20II), 'Macroprudential policy: the need for a coherent policy framework', Duisenberg School of Finance Policy Paper No.I 3.

-(20I5), 'Regulating the financial cycle: an integrated approach with a leverage ratio', Economics Letters, 136, pp. 70-72.

Schularick, M. and Taylor, A. (2012), 'Credit booms gone bust: monetary policy, leverage cycles and financial crises, 1870-2008', American Economic Review, 102, Pp. 1029-6I.

Schüler, Y., Hiebert, P. and Peltonen, T. (20I5), 'Characterising the financial cycle: a multivariate and time-varying approach', ECB Working Paper No. 1846.

Shleifer, A. and Vishny, R. (20II), 'Fire sales in finance and macroeconomics', Journal of Economic Perspectives, 25, pp. 29-48.

Stein, J. (2013), 'Overheating in credit markets: origins, measurement, and policy responses', remarks at a Research Symposium sponsored by the Federal Reserve Bank of St. Louis, 7 February.

Tucker, P. (2014), 'The political economy of macroprudential regimes', in Schoenmaker, D. (ed.), Macroprudentialism, London, CEPR: VoxEU eBook, pp. 6I-72. 